\title{
Sustainable tourism and the Sustainable Development Goals in sub-national island jurisdictions: The case of Tobago
}

\section{Preeya S. Mohan}

Sir Arthur Lewis Institute of Social and Economic Studies, University of the West Indies, St. Augustine, Trinidad \& Tobago

Preeya.Mohan@sta.uwi.edu

\begin{abstract}
Tourism has the potential to contribute to achieving the Sustainable Development Goals (SDGs) agreed to by United Nations member states. For sustainable tourism to be successful, stakeholders must be involved in the process. The aim of this study is to consider the extent to which sustainable tourism contributes to achieving the SDGs and how tourism stakeholders understand and implement sustainable tourism. Specifically, the study adopted a qualitative approach and used the case study of Tobago. The data were collected using focus groups of tourism stakeholders. The research revealed that stakeholders embraced the SDGs despite a lack of understanding. They were unable to provide a comprehensive definition of sustainable tourism and their relation to the SDGs, but recognised its traditional components along with specific island features. Stakeholders more easily listed sustainable tourism practices and potential and their link to the SDGs. The barriers to sustainable tourism centred mainly on the role of the local governing body and political affiliation, dependency on the mainland, and prohibitive costs. Action is needed to facilitate broader stakeholder awareness and collaboration in support of efforts to enhance sustainable tourism and the achievement of the SDGs, where policymakers need to act as a catalyst for change.
\end{abstract}

Keywords: sustainable tourism, Sustainable Development Goals, sub-national island jurisdiction, Tobago

https://doi.org/10.24043/isj.183 • Received May 2021, Early access October 2021

(C) Island Studies Journal, 2022

\section{Introduction}

Tourism is placed among the largest and fastest growing industries in the world, and forecasts of growing international tourism have made the sector a key channel for achieving the Sustainable Development Goals (SDGs). The United Nations World Tourism Organization (UNWTO) proclaimed 2017 as the International Year of Sustainable Tourism for Development to highlight the potential of the industry to advance the achievement of the SDGs. Pre COVID-19, global travel and tourism growth 
was 3.5\% and accounted for $10.3 \%$ of world GDP and $10 \%$ of world employment (World Travel and Tourism Council, 2019). While COVID-19 brought international travel to a standstill, tourism remains resilient with significant capacity to bounce back (World Tourism Organization [UNWTO], 2020). Post-COVID-19, tourism would continue to be important for small islands. The theme of the Annual Report on Global Islands 2019 (Randall, 2020) was to examine the role of international tourism for the sustainable development of islands.

Tourism is often the only type of economic activity available on islands, and contributes significantly to GDP, employment, and foreign exchange earnings (Mooney \& Zegarra, 2020; Royle, 2001). Islands are among the most tourism-penetrated destinations globally (Baldacchino, 2006; Kelman, 2021; McElroy, 2003; Mooney \& Zegarra, 2020). Overtourism has also become a major concern for small islands (Dodds \& Butler, 2019; Milano et al., 2018; Peterson, 2020). According to Baldacchino (2004), given that sustainable development is already a challenge in small islands, sustainable tourism is even more impossible in sub-national island jurisdictions (SNIJs).

Tourism has the potential to contribute, directly or indirectly, to achieving all of the SDGs. Tourism development is multifaceted and can have positive and negative effects on the economy, environment, and community. As such, sustainability and the SDGs have become important concepts for tourism development and planning (Grydehøj \& Kelman, 2017; Hall, 2019; Kelman, 2021). The SDGs seek to facilitate broad-based sustainable development through its focus on partnerships as a means of implementation (Movono \& Hughes, 2020). A lack of awareness of the SDGs by stakeholders, however, poses practical challenges that are difficult to overcome (Özgit \& Zhandildina, 2021). Nevertheless, there has been very little work done, especially in small developing islands (Rasoolimanesh et al., 2020), to demonstrate how tourism stakeholders can embrace sustainability and the SDGs to ensure a more sustainable tourism future.

The present study adds to the limited theoretical and empirical research on sustainable development, the SDGs, and sustainable tourism in small islands. The aim of this study is to consider the extent to which sustainable tourism contributes to achieving the SDGs and how tourism stakeholders understand and implement sustainable tourism. Specifically, the study sought to:

- understand the general perception of tourism stakeholders concerning their knowledge of sustainable tourism and the SDGs;

- discern sustainable tourism practices and potential for development related to the implementation of the SDGs; and

- identify sustainable tourism barriers related to the implementation of the SDGs.

The study adopted a qualitative approach and presents a case study of Tobago. Data were collected through focus groups comprising key tourism stakeholders. Tobago is 
an apt case study, as it is highly tourism oriented, with tremendous potential to expand the industry, and opportunities for the promotion of sustainable tourism practices.

\section{Theoretical considerations}

Tourism is related to sustainable development, and is also related to the SDGs, given that they are the blueprint to achieve a better and more sustainable future for all. Tourists travel to a destination which provides the tourism product; in turn, it is in the destination's best interest to achieve its SDGs, as they facilitate broad-based sustainable development. These actions include preservation of cultural and natural resources for tourism purposes, which benefits future generations. This allows for sustainable development principles and practices to be established in the social consciousness of tourism stakeholders (Özgit \& Zhandildina, 2021). The prevailing view in the literature is that sustainable tourism can embrace and balance commercial, environmental, and social needs (Rasoolimanesh et al., 2020). Further, a sustainable development approach is vital for tourism, and sustainable tourism is viewed as a step towards sustainable development. However, there are still many ongoing debates about the precise definition of 'sustainable tourism' and its applicability, how to approach and secure the twin objective of sustainable tourism and sustainable development, and who should be responsible for implementation and monitoring. Further, the literature does not provide a comprehensive framework to effectively involve stakeholders in the implementation of sustainable tourism and the SDGs. Additionally, there is a dearth of theoretical and empirical research that can inform stakeholder involvement in the process (Movono \& Hughes, 2020).

\subsection{Sustainable tourism}

Tourism is identified as one of the key industries that could make a positive contribution to a sustainable planet (Berry \& Ladkin, 1997; Grydehøj \& Kelman, 2017; Hall, 2019; Kelman, 2021). Tourism by its very nature can have both positive and negative effects on the community, economy, and environment (Gunn, 1994). Furthermore, if tourism development is not planned properly, it could destroy the very resources that are the foundation of the industry (Choi \& Sirakaya, 2006; Inskeep, 1991; McCool, 1995). For tourism development to be successful, it must be planned and managed in a sustainable manner (Inskeep, 1991; McCool, 1995; Southgate \& Sharpley, 2002; Yuksel et al., 1999). Consequently, sustainability has become an important topic and concept in relation to tourism planning and development (Inskeep, 1991; Southgate \& Sharpley, 2002; Yuksel et al., 1999). Bramwell and Lane (1993) provide a comprehensive review of the historical development of sustainable tourism as a concept.

Many authors have provided various definitions of sustainable tourism (Gunn, 1994; Hardy \& Beeton, 2001; Ioannides, 1995; Robson \& Robson, 1996). While there is no universally accepted definition, one of the most widely used is that developed by the World Tourism Organization (1998, p. 21), which defines sustainable tourism as: 


\begin{abstract}
Development that meets the needs of present tourists and host regions while protecting and enhancing opportunities for the future. It is envisaged as leading to management of all resources in such a way that economic, social, and aesthetic needs can be fulfilled while maintaining cultural integrity, essential ecology processes, biological diversity, and life support systems.
\end{abstract}

Furthermore, sustainable tourism is not a static process; its objectives must be flexible and adaptable as it continuously searches for new answers (Byrd, 2007). This lack of precision in defining sustainable tourism has raised questions about its applicability, implementation, and monitoring (Choi \& Sirakaya, 2006; Ko, 2005). Further, despite the acceptance of sustainable tourism as a desirable model of development, large gaps still exist between endorsement and implementation (Pigram, 1990).

\title{
2.2. Small Island Developing States
}

At the 1992 United Nations Conference on Environment and Development, Small Island Developing States (SIDS) were recognized as a special case of developing countries. SIDS make up less than $1 \%$ of the world's population and face unique social, economic, and environmental challenges, including their small size, remoteness, narrow resource and export base, and exposure to environmental challenges and external economic shocks. As SIDS seek to address these structural and external challenges, they have strongly committed to achieving the SDGs - and require international support and partnership to do so. In 1994, the Barbados Program of Action (BPoA) prescribed actions that would enable SIDS to achieve sustainable development at the national, regional, and international levels. Following this, the Mauritius Strategy for further implementation of the BPoA was adopted in 2005 to address remaining gaps in implementation. The SAMOA Pathway in 2004 recognised the adverse impacts of climate change and sea-level rise on SIDS' efforts to achieve economic development, food security, disaster risk reduction, and ocean management.

\subsection{Sustainable island tourism}

The impact of tourism is more sudden, pervasive, transparent, and irrevocable in small islands (Apostolopoulos \& Gayle, 2002; Briguglio et al., 2006; Kelman, 2021; Peterson, 2020). Grydehøj and Kelman (2017) point out that islands engage in symbolic sustainability initiatives that may not necessarily contribute to sustainability, and argue that islands should pursue locally contextualised development around climate change adaptation. Sustainable tourism is, hence, a far bigger challenge, where the capacity to implement sustainable tourism practices is often limited, with huge negative environmental and social consequences (Baldacchino, 2004). Island sustainability influences and is influenced by tourism resources (Kelman, 2021). For islands, there is similarly no single definition, or consensus on the objectives, applicability, or feasibility of sustainable tourism (Twining-Ward \& Butler, 2002). A commonly used definition comes from McElroy and Albuquerque (2002, p. 16) which 
states that, ideally, sustainability in island tourism "seeks to preserve a permanent and widely shared stream of income by creating an adaptive competitive destination niche market through the on-going guidance of participatory community planning without unacceptably sacrificing the socio-cultural and natural integrity of the asset base."

Lim and Cooper (2008) identified four challenges facing sustainable tourism development in islands: limited environmental resources, need for community involvement, powerlessness, and challenges from special interest activities. In SNIJs, transport is a triple problem of choice, time, and price, and this can negatively affect the viability of the tourism industry (Armstrong \& Read, 1998, 2000; Baldacchino, 2004). On the other hand, SNIJs have the advantage of a ready source market, joint destination marketing, access to investment capital, aid financed transport, communication infrastructure, and special tax and duty free concessions (McElroy \& Mahoney, 1999). Further, tourism is a safe policy domain that does not threaten the authority of the mainland administration (Baldacchino, 2006; McElroy, 2003). Administrative autonomy also gives SNIJs control over the management of their tourism sector. Lelaulu (1994) suggested that, in managing tourists in islands, there should be zoning and an aim to attract fewer long-stay tourists. Islands should also showcase their charm, history, and culture, and involve the community (Lelaulu, 1994).

\subsection{Sustainable tourism and the SDGs}

Sustainable tourism can increase economic growth, as well as improve people's quality of life, support environmental protection and diverse cultural heritage, and strengthen world peace. The tourism industry has been specifically included as targets in Sustainable Development Goals 8 (Decent work and economic growth), 12 (Responsible production and consumption), and 14 (Life below water) (UNWT0, 2015). Sustainable tourism, however, has the potential to contribute, directly or indirectly, to all 17 of the SDGs across economic, social, and environmental domains.

Challenges faced in making tourism sustainable, such as unsustainable consumption and production, management of natural and cultural resources and waste, can negatively impact the SDGs, in particular Goal 11 (Sustainable cities and communities), Goal 12 (Responsible production and consumption), and Goal 14 (Life below water) (UNWTO, 2015). Further, tourism's potential to advance the SDGs is undermined by external threats such as global economic instability, natural disasters, climate change, the loss of biodiversity, and regional and international security (UNWTO, 2015). These threats are seen as mostly affecting progress on Goal 8 (Decent work and economic growth), Goal 11 (Sustainable cities and communities), Goal 13 (Climate action), Goal 15 (Life on land), and Goal 16 (Peace, justice, and strong institutions).

The International Year of Sustainable Tourism for Development in 2017 sought to provide the impetus for countries to better focus actions which support tourism's contribution to sustainable development, while promoting the inclusion of tourism within their development policy frameworks (UNWTO, 2018). Five key areas were identified to provide a framework for tourism stakeholders to consider how their 
actions and tourism initiatives can better contribute to sustainable development and the SDGSs, including: (1) sustainable economic growth; (2) social inclusiveness, employment, and poverty reduction; (3) resource efficiency, environmental protection, and climate change; (4) cultural values, diversity, and heritage; and (5) mutual understanding peace and security (UNWTO, 2018).

\subsection{Tourism stakeholders, sustainable tourism, and the SDGs}

Tourism research tends to look at sustainability and stakeholders from a macro perspective and react to stakeholder demands in a generalized, non-coordinated manner, without considering contradictions and overlaps in stakeholder demands (Özgit \& Zhandildina, 2021). There has been considerably less focus on the reasons why certain stakeholder groups advocate for or oppose different sustainable standards and practices. Such an approach can, however, facilitate the uncovering of synergies between stakeholders and specific SDG action. It allows for the identification of actionable ways of dealing with stakeholders' perceptions of the opportunities and obstacles related to the actual implementation of sustainable tourism and the SDGs. Nevertheless, there is a paucity of theoretical and empirical literature on sustainable tourism and the SDGs, especially in developing islands.

Among limited studies, Movono and Hughes (2020) examined how partnerships between tourism businesses and local community stakeholders can support local development outcomes and contribute to the attainment of the SDGs in Fiji. The findings indicate that partnerships are integral to enabling meaningful local development outcomes, while noting points of disconnect. Rasoolimanesh et al. (2020) examined the relevance of sustainable tourism indicators to the SDGs and stakeholders involved through a review of the literature. The study showed a lack of attention to the SDGs after their launch, although the majority of the SDGs and their targets were indirectly covered. Further, many studies focused on European countries rather than developing countries and small islands. A study by Özgit and Zhandildina (2021) investigating how tourism stakeholders in North Cyprus understand and implement the SDGs revealed that not all of the SDGs have been embraced, and that there is lack of understanding about the goals and about the need for collaboration among the different tourism stakeholders.

\section{The case study}

The case study of this research is the island of Tobago. Tobago can be described as a SNIJ, and is part of the twin island republic of Trinidad and Tobago, located in the Caribbean region (see Figure 1). Tobago has been a ward of Trinidad since 1899. Trinidad is the main island of the republic and is $4,828 \mathrm{~km}^{2}$ with a population of $1,308,126$, whereas Tobago is much smaller at $300 \mathrm{~km}^{2}$ with a population of 60,874 . The economy of Trinidad and Tobago is dominated by oil and gas, and the majority of these activities take place in Trinidad. In Tobago, the primary economic activity is tourism. Tourism is viewed as a key sector for diversification away from oil and gas, 
and for sustainable development of the economy of Trinidad and Tobago. Table 1 shows that international tourist arrivals to Trinidad and Tobago are relatively low compared to other Caribbean islands, and have been falling recently. Further, between March 2020 and July 2021, the COVID-19 pandemic resulted in the country closing its borders bringing tourism to a standstill.

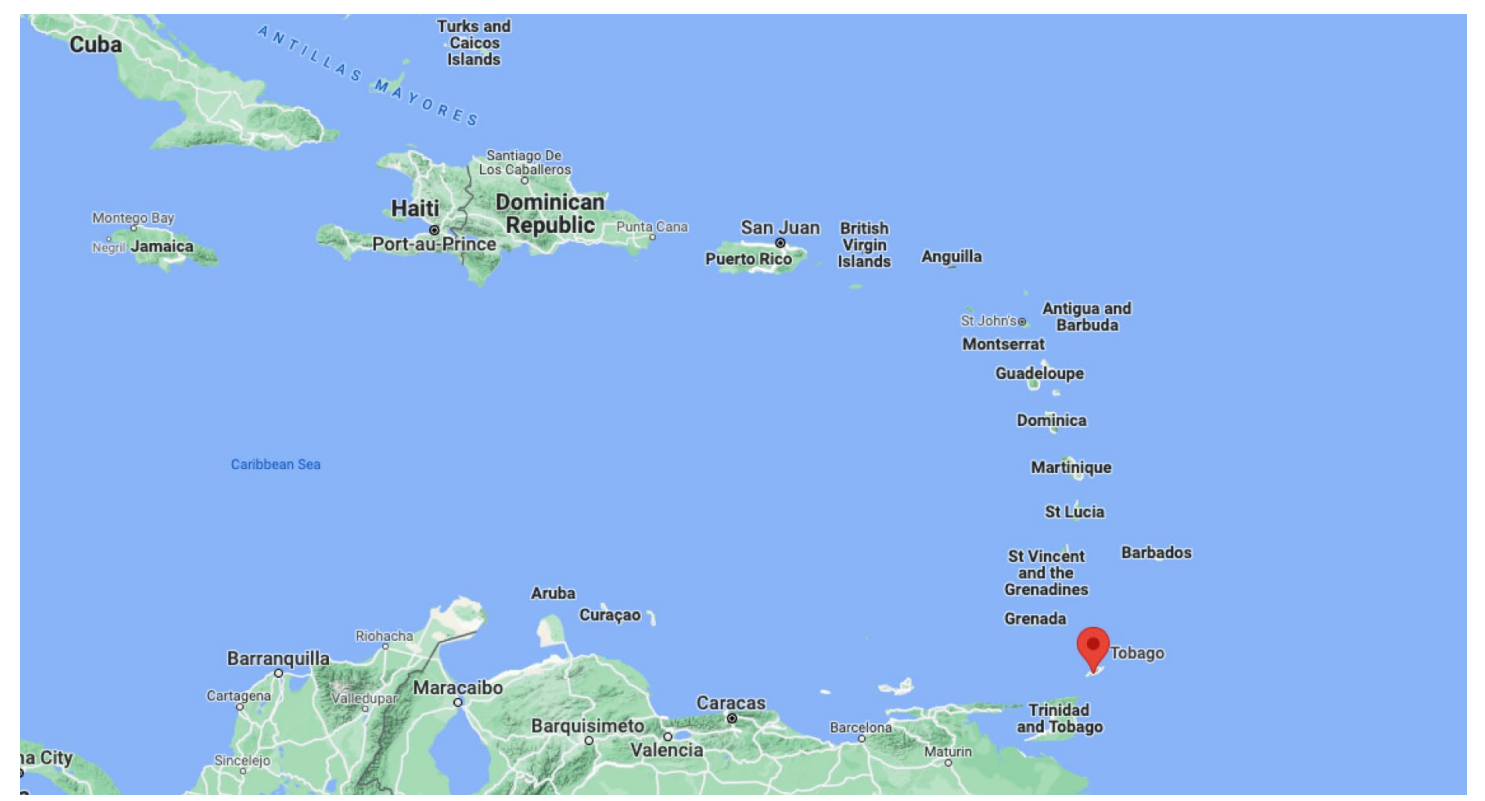

Figure 1: Map indicating location of Tobago. Source: Instituto Nacional de Estadística y Geografía \& Google, 2021.

Local government and central government in Tobago are handled by the Tobago House of Assembly (THA). There are seven administrative divisions, and Tobago has two parliamentary seats out of a total of 41. The Government of Trinidad and Tobago is committed to the SDGs. Vision 2030: The National Development Strategy of Trinidad and Tobago 2016-2030 (Government of the Republic of Trinidad and Tobago, 2016) incorporates the goals across the three dimensions of sustainable development: economic, social, and environmental. The Division of Tourism, Culture and Transportation is the arm of the THA responsible for policy and planning for tourism development in Tobago. The Tobago Tourism Agency Limited was established in July 2017 in order to meet the needs of stakeholders (Tobago Tourism, n.d.). The Agency was founded on the principles of sustainable development and has oversight for marketing the destination, product development and innovation, as well as cruise and airlift. The majority of businesses in Tobago are small employing just one person (see Table 2). These businesses operate in the tourism sector and include restaurants, bars, and retail shops. There are over 46 non-governmental organisations (NGOs) in Tobago, as well as NGOs in Trinidad which offer programs in Tobago (T\&T NGO News, n.d.). While there is no university in Tobago, there are satellite campuses and distance education facilities.

Tobago has many natural attractions to offer the traditional 'sun, sea, and sand' holidays, including the Buccoo Reef and Nylon Pool. Additionally, there has been 
progress to develop nature and ecotourism, local culture and heritage tourism, and, most recently, cruise, yachting, and diving. The island is home to the Main Ridge Forest Reserve, which is the oldest forest reserve in the Western hemisphere. Little Tobago is world famous for bird watching. The Tobago Heritage Festival is an annual celebration of Tobago's unique cultural heritage which showcases the dance, song, music, and cuisine of the island. As the most southern of the Caribbean islands, Tobago has, for the most part, escaped devastating hurricanes which frequently hit the region. In addition, Tobago has a prime geographical location in the Caribbean Sea offering easy access to its major source markets for tourist arrivals, namely North America, the United Kingdom, and Europe. Trinidadians also frequently visit Tobago in large numbers thereby creating a large domestic tourist subsector. Tobago has one international airport, and there is also a ferry service between Tobago and Trinidad. Visitors to Tobago can choose from large luxurious resorts and villas, as well as smaller familyrun bed and breakfasts and self-catering apartments.

According to Invest Trinidad and Tobago (InvesTT, 2019), tourism accounts for $50 \%$ of the Tobago's GDP and in excess of $56 \%$ of the workforce is employed in the industry. Since the 2007-2008 international financial crisis, tourist arrivals in Tobago have been falling. Table 3 shows that the net occupancy rate for Tobago was $44.8 \%$ in 2013, and dropped to $32.1 \%$ in 2017 (based on latest available data). This is much lower than Trinidad's net occupancy rate of $67 \%$ in 2015. Domestic tourists from Trinidad have become the mainstay of Tobago's tourism industry. In 2013, the TDC (the republic's Tourism Development Company) estimated that there had been a total of 626,654 domestic tourists in Tobago, which represented an increase of almost $60 \%$ from 2009. These visitors save significantly on travel expenses, which are subsidized by the government, and visitors can easily take across food, drinks, and other items. Falling tourist arrivals have made the economy of Tobago heavily dependent on the THA for employment and government expenditure, which comes out of the national budget for Trinidad and Tobago.

In 2012, the Comprehensive Economic Development Plan 2013-2017 (CEDP) was developed to restructure and transform Tobago. The plan fits well with the SDGs, with an emphasis on implementation of sustainable development, and it identifies sustainable tourism as a key sector for developing Tobago. The objective is to develop the industry in a sustainable, culturally and environmentally sound manner that supports a high standard of living and enhanced contribution of the tourism sector to sustainable and inclusive growth. Tobago's dependence on domestic tourism must be balanced by increased diversification within the sector, with a search for new source markets in Latin America and Asia. The tourism base would be expanded to offer ecotourism, cultural and heritage tourism, events tourism, community tourism, health and wellness tourism, research tourism, and sports tourism. 
Table 1: International Tourists Arrivals (World Bank Group, 2021).

\begin{tabular}{lrrrrrr}
\hline Country & $\mathbf{1 9 9 5}$ & $\mathbf{2 0 0 0}$ & $\mathbf{2 0 0 5}$ & $\mathbf{2 0 1 0}$ & $\mathbf{2 0 1 5}$ & $\mathbf{2 0 1 9}$ \\
\hline Antigua and Barbuda & 447,000 & 634,000 & 712,000 & 788,000 & 894,000 & $1,035,000$ \\
Aruba & 912,000 & $1,211,000$ & $1,286,000$ & $1,394,000$ & $1,832,000$ & $1,951,000$ \\
Bahamas, The & $3,239,000$ & $4,204,000$ & $4,779,000$ & $5,255,000$ & $6,112,000$ & $7,250,000$ \\
Barbados & 927,000 & $1,078,000$ & $1,111,000$ & $1,197,000$ & $1,179,000$ & 966,000 \\
Bermuda & 557,000 & 539,000 & 517,000 & 580,000 & 597,000 & 805,000 \\
Cayman Islands & $1,044,000$ & $1,385,000$ & $1,967,000$ & $1,886,000$ & $2,102,000$ & $2,334,000$ \\
Curacao & 396,000 & 514,000 & 510,000 & 762,000 & $1,072,000$ & $1,293,000$ \\
Dominica & 203,000 & 312,000 & 381,000 & 595,000 & 358,000 & 322,000 \\
Grenada & 369,000 & 316,000 & 380,000 & 445,000 & 437,000 & 526,000 \\
Jamaica & $1,752,000$ & $2,230,000$ & $2,615,000$ & $2,832,000$ & $3,692,000$ & $4,233,000$ \\
Puerto Rico & $4,087,000$ & $4,566,000$ & $5,073,000$ & $4,379,000$ & $5,051,000$ & $4,931,000$ \\
St. Lucia & 407,000 & 727,000 & 720,000 & 984,000 & $1,031,000$ & $1,220,000$ \\
St. Kitts and Nevis & 203,000 & 247,000 & 365,000 & 624,000 & $1,036,000$ & $1,107,000$ \\
St. Vincent and the & 218,000 & 256,000 & 256,000 & 231,000 & 207,000 & 392,000 \\
Grenadines & 282,000 & 503,000 & 529,000 & 490,000 & 519,000 & 480,000 \\
Trinidad and Tobago & & & & &
\end{tabular}

Table 2: Firm by employment size, Trinidad and Tobago (Central Statistical Office of Trinidad and Tobago, 2019).

\begin{tabular}{lrrrrrrrrrr}
\hline & \multicolumn{10}{c}{ Employment group size } \\
\cline { 2 - 11 } & $\mathbf{0 - 1}$ & $\mathbf{2 - 4}$ & $\mathbf{5 - 9}$ & $\mathbf{1 0 -}$ & $\mathbf{2 5 -}$ & $\mathbf{5 0 -}$ & $\mathbf{1 0 0}-$ & $\mathbf{2 5 0 - 5 0 0}$ & $\mathbf{5 0 1 - 9 9 9}$ & $\mathbf{2 1 0 0 0}$ \\
\cline { 2 - 11 } Tobago & 609 & 168 & 101 & 64 & 12 & 11 & 5 & 3 & 0 & 0 \\
Trinidad & 6,942 & 3,829 & 2,123 & 1,793 & 741 & 397 & 250 & 112 & 37 & 20 \\
\hline Total & 7,551 & 3,997 & 2,224 & 1,857 & 753 & 408 & 255 & 115 & 37 & 20 \\
\hline
\end{tabular}

Table 3: Visitors to Tobago, by type and year (Tobago House of Assembly, 2019).

\begin{tabular}{|c|c|c|c|c|c|c|c|}
\hline \multirow[b]{2}{*}{ Year } & \multicolumn{5}{|c|}{ Passenger/visitor type } & \multirow[b]{2}{*}{$\begin{array}{c}\text { Total } \\
\text { visitors }\end{array}$} & \multirow[b]{2}{*}{$\begin{array}{c}\text { Net } \\
\text { occupancy }\end{array}$} \\
\hline & Ferry & $\begin{array}{c}\text { Air } \\
\text { (Domestic) }\end{array}$ & $\begin{array}{c}\text { Air } \\
\text { (International } \\
\text { ) }\end{array}$ & Yacht & Cruise & & \\
\hline 2013 & 506,769 & 441,698 & 31,929 & 1,082 & 20,274 & $1,001,752$ & $44.8 \%$ \\
\hline 2014 & 469,998 & 463,667 & 32,904 & 886 & 29,735 & 997,190 & $44.2 \%$ \\
\hline 2015 & 452,145 & 482,957 & 28,105 & 867 & 64,657 & $1,028,731$ & $40.8 \%$ \\
\hline 2016 & 418,087 & 479,409 & 26,935 & 796 & 53,486 & 978,713 & $38.3 \%$ \\
\hline 2017 & 249,428 & 483,034 & 28,019 & 753 & 37,278 & 798,512 & $32.1 \%$ \\
\hline Avg. & 419,285 & 470,153 & 29,578 & 877 & 41,086 & 960,980 & $40.0 \%$ \\
\hline
\end{tabular}

\section{Methodology}

The study adopted a qualitative approach, and used focus groups to collect data on sustainable tourism in SNIJs, looking at the case of Tobago. Since the 1980s, focus groups have been widely used in social sciences research. A focus group takes the form of a structured discussion with a small group of people, run by a moderator to generate qualitative data on a specific research topic using open ended questions (Boddy, 2005; 
Prince \& Davies, 2001). The focus group is intended to collect data, through interactive and directed discussions by the researcher or moderator. Focus groups enable the researcher to attain in-depth insights, perceptions, and opinions into the research topic from a small number of people in a short period of time (Barrows, 2000; Hines, 2000; Krueger, 1994), and are generally useful for obtaining valuable information when investigating unexplored or new topics (Threlfall, 1999). Focus groups allow for cumulative group discussion which leads to a wider opinion than from a single individual; there is security in group numbers, ideas can be debated, and comments can provoke further discussion.

Special care must be taken to ensure the appropriate configuration of participants, facilitators, length, setting, and so on, to ensure the quality and validity of focus group data. There is no fixed rule on group size, although groups between 4 to 12 are common (Boddy, 2005; Krueger, 1994; Prince \& Davies, 2001). A group should, however, be small but demographically diverse and, at the same time, homogeneous (Boddy, 2005). The research topic may determine group composition. From the literature the length of sessions should be between half an hour to two-and-a-half hours long (Stewart \& Shamdasani, 1990), although sessions over two hours are preferred (Nielsen, 1997; Schmidt, 2001). The priority should be to get the maximum amount of information possible over the time period.

For this research, three focus groups were conducted. Participants were chosen using a purposive snowball sampling method. Each group consisted of a different mix of tourism stakeholders. Group 1 was 'social partners' and comprised government officials or representatives, businesses, and workers/trade unions. Group 2 was 'civil society' and consisted of academics, NGOs, and youth. Group 3 was made up of families and households. The groups were purposely constructed so that each group had a distinctive identity which reflected sustainable tourism development in Tobago. This also made it easier to navigate issues of power and interest among stakeholders. The use of the three groups allowed for diverse views across each stakeholder category. All groups were asked the same questions, which are listed in Table 5. All of the stakeholders who attended play critical roles in sustainability policy and solutions on the island. Not all participants were born in Tobago but they do live in Tobago and have been doing so for a number of years. A summary of focus group participants is presented in Table 4. 
Table 4: Summary of Focus Group Participants.

\section{Group 1}

Stakeholder group: Social partners (Government, private sector, and workers/trade unions)

Date: Wednesday $4^{\text {th }}$ December 2019

Number of focus group participants: 3

Group composition: Participant 1- Government worker (male)

Participant 2- Small business owner (female)

Participant 3- Private sector worker (female; youth)

\section{Group 2}

Stakeholder group: Civil society (academics, NGOs, youth)

Date: Wednesday $4^{\text {th }}$ December 2019

Number of focus group participants: 6

Group composition: Participant 4- NGO head (male)

Participant 5- Member of a NGO (female)

Participant 6- Academic (male)

Participant 7- Youth (government worker; female)

Participant 8- Youth (private sector worker; female)

Participant 9- Youth (private sector worker; female)

\section{Group 3}

Stakeholder group: Households

Date: Thursday $5^{\text {th }}$ December 2019

Number of focus group participants: 5

Group composition: Participant 10- Female headed household (mother and academic)

Participant 11- Nuclear household (father and private sector worker)

Participant 12- Nuclear household (mother and small business owner)

Participant 13- Nuclear household (father and government worker)

Participant 14- Female headed household (mother and private sector worker)

Table 5: Focus Group Questions (compiled by author).

\section{SDGs}

1 What do you know about the United Nation's Sustainable Development Goals?

2 What is your assessment of how Tobago has done in trying to meet these Sustainable Development Goals?

\section{Sustainable tourism}

3 What does sustainable tourism mean to you?

4 Do you believe that tourism is being managed in a sustainable manner in Tobago? Why or why not?

5 Do you have any specific suggestions on strategies to ensure that future tourism in Tobago is managed in a sustainable manner? 


\section{Results}

The analysis and coding of the focus group data involved categorising the data into themes using the responses provided by the participants. The framework analysis method was used to interpret the raw data via a coding process. The study assigned meaning to the information gathered by categorising, comparing, and clustering the data until the point was reached when no new insights emerged. The resultant themes revealed information regarding sustainable tourism perception; sustainable tourism practices and potential; and barriers to sustainable tourism, and their relation to the SDGs. An important feature of the results is that, across different stakeholder categories, each group shared similar views and concerns, and presented similar solutions.

\subsection{SDGs and sustainable tourism perception}

Focus group participants were asked about their awareness of the SDGs. Most participants had some awareness of the SDGs, but lacked more detailed knowledge. As the goals were mentioned, stakeholders were able to relate the SDGs to their own actions and fully embraced them as important for development in Tobago. Stakeholders were given the opportunity to define conceptually what sustainable tourism in Tobago means to them. While all participants had an opinion on what sustainable tourism means, no clear definition of the concept was presented. Moreover, some individuals expressed concern about not being able to define 'sustainable tourism' and stated that the concept was difficult to measure. Further, one participant articulated that what is considered important today can change in the future, and elaborated that the concept of sustainable tourism is not fixed but can change over time. Another contributor stated, "honestly, I can't define it [sustainable tourism]," and referred to sustainable tourism as an "oxymoron," further asserting, "I'm not sure how they [sustainable and tourism] go together [...] because if you are too successful you can destroy the environment or lose your sense of identity."

Participants were, nonetheless, able to identify key components of sustainable tourism and relate these to the SDGs. All three stakeholder groups defined sustainable tourism as meeting the needs of current and future generations. Words and phrases such as "continuously develop," "stay," "sustained," "longevity," "ongoing activity," and "maintain" were used. A sentiment shared by some was that if tourism is not developed on the island, nothing else would develop. According to one stakeholder, "Tobago was left to do tourism." The entire island of Tobago is tourism-driven and all businesses, communities, and households on the island are affected by what happens in the sector. Tourism is viewed as having positive and negative effects on the Tobago economy, environment, and community, and sustainable tourism and the SDGs aim to reduce these negative effects. Also, participants felt that if tourism development on the island is not properly planned, it could destroy the very resources that are the foundation of the industry. 
The economic, environmental, and social components of sustainable tourism which overlap with the SDGs were put forward by participants. Tourism was identified as the main economic driver on the island that could make a positive contribution to the development of other sectors such as agriculture and fishing, food and beverage, and craft. Tourism could boost investment (both foreign and domestic), income, employment, and entrepreneurship on the island. Additionally, the conservation and preservation of flora and fauna and ecosystems, effective management of resources, and adaptation to (and mitigation of) climate change were viewed as paramount for the future of tourism on the island. Tobago's natural environment and attractions such as the Buccoo Reef and Protected Rainforest Reserve were regarded as vital assets which attract visitors. This was summed up in the phrase, "it is natural resources people come here to enjoy - sun, sand and sea." Also, preservation of the built environment, including old colonial buildings and landmarks such as tunnels and sugar mills, was deemed important. The social aspect of sustainable tourism was also brought up. This involved maintaining Tobago's unique heritage and culture, social order and social structure, and staying true to its identity. Community involvement, participation, and support were believed to be most important for meeting the economic and environmental objectives of sustainable tourism.

Given that Tobago is physically cut off from Trinidad, reliable transport links, both international and domestic, to get people to the destination are necessary in order for tourism to develop and thrive. This point was brought up across all three focus groups. Management of and research on the carrying capacity of Tobago, especially in ecologically sensitive areas such as the Buccoo Reef, was another key aspect of sustainable tourism brought up in discussion. Additionally, Trinidad acts as a safety net for Tobago and, as such, the tourism sector may not be viewed as fundamental in Tobago. The island of Trinidad, often referred to as the 'mainland', provides a ready source market for visitors throughout the year. Also, Tobago receives its annual budgetary allocation from the central government funded mainly by tax revenue from the oil and gas sector, together with institutional and policy support. A view expressed in the focus groups was that the people of Tobago do not see the benefits and potential of sustainable tourism because of this dependency relationship with the mainland.

\subsection{Sustainable tourism practices and potential}

Participants identified practical action and potential areas to expand and develop sustainable tourism in Tobago that may also contribute to achieving the SDGs. These sustainable tourism practices seek to reduce the negative effects of tourism and expand the benefits. 'Sustainable tourism potential' refers to areas where some positive action is taking place but there is room for improvement, as well as completely new possibilities. The recognition and description of sustainable tourism practices and potential indicate that, despite some vagueness and uncertainty surrounding the definition of sustainable tourism, positive steps are being taken in Tobago. These positive actions include developing a reliable transport link to the island; improved tourism product development and destination marketing; developing a model of 
community tourism that is sustainable; individual action such as recycling and energy conservation; and ecological research, management, protection, and conservation (discussed in more detail below). There is, however, potential for more to be done.

A reliable transport link is a primary workable practice for sustainable tourism in Tobago and is connected to Goal 9 (Industry, innovation, and infrastructure). This was recognised across all three focus groups. Respondents felt that improved access to Tobago could translate into more tourists and more efficient travel, thereby reducing negative environmental impacts. Tobago is, however, not easily accessible to domestic and international tourists. If tourists are not able to get to Tobago, sustainable tourism is not possible. There are frequent complaints that Trinidadians are unable to get a flight or ferry across to Tobago, despite making up a significant portion of arrivals to the island. Current inter-island transports by air and sea are unable to satisfy demand. Moreover, disruptions regularly occur on the 'sea bridge' - serviced by ferries and other vessels - because of overbooking, bad weather, and aged ferries which result in numerous breakdowns and significant down time for maintenance and repairs. This, in turn, places extra pressure on the 'air bridge', which does not have sufficient capacity for the extra load. Reliable transport links are also necessary to get much-needed supplies from the mainland, which are important inputs into the tourism industry, since a lack of economies of scale makes production inefficient in Tobago. As there are few direct international flights to Tobago, many international tourists have to travel via Trinidad and, therefore, face the unreliability of transport links between the islands. Consequently, many travellers may choose to stay in another Caribbean destination where they can get a direct flight. A potential solution proposed in the focus groups was to create more direct links to new source destinations closer to the Caribbean, including Central and South America. While this may attract increased visitors once direct links are created, it would require upgrades to the existing airport in Tobago.

The commercial viability of Tobago as a destination - including product quality, attractiveness, price, and customer service - was also raised as a crucial issue. Sustainable tourism cannot develop on the island if the tourism product being offered is not commercially viable. Tourism in Tobago has been on the decline, which threatens Goal 8 (Decent work and economic growth). One participant stated that "the island is no longer regarded as a top destination in the region"; this is evidenced by a fall in tourist arrivals and the closure of hotels and guest houses in recent times, while arrivals have significantly increased in competitor Caribbean territories. Hotel rooms on the island are also overpriced compared to other Caribbean destinations, and tourists coming to the island criticize the standard of the hotels and the quality of rooms (to that end, accommodations in Tobago are currently being upgraded through COVID-19 grants from the government). Food and beverage and other supplies are also more expensive in Tobago because all products have to be transported from Trinidad, making the island uncompetitive from a price perspective. Stakeholders also stated that a common feedback provided by tourists is that there is poor customer service on the island.

Destination marketing was perceived as an effective means to attract visitors. A common belief among participants was that travellers think of Tobago as a "sun, sea, 
and sand" destination and are not fully aware of what the island has to offer in terms of its natural environment and culture; there is no 'destination awareness'. In the past, there was one governing body with overall responsibility for tourism development and marketing in Trinidad and Tobago. When Trinidad and Tobago were promoted jointly, however, a confused message was sent to the marketplace. As one participant recounted, "whenever we went to travel market, we'd have oil rigs on one side and beaches on the other, and it didn't work, it never worked." The government recently created the Tobago Tourism Agency, which is responsible for marketing and product development of Tobago alone, separate from Trinidad. This had been pushed for by the Tobago private sector for a very long time, and participants agreed that this was a welcomed move; Tobago as a destination is being highlighted more. That said, there is no marketing specifically targeting Trinidad, which provides a domestic ready market that is not fully utilised. According to one respondent, "Tobagonians just expect that Trinidadians would come."

Stakeholders recognised household or individual level action as positively affecting sustainable tourism. These actions include proper garbage disposal and recycling, clean-up campaigns, and energy conservation, all of which are linked to Goal 6 (Clean water and sanitation), Goal 7 (Affordable and clean energy), and Goal 11 (Sustainable cities and communities). Stakeholder comments indicated ways in which positive local action can be taken on a small scale. With regard to garbage disposal, persons in Tobago try their best to get rid of their waste properly. It was, however, stated that garbage is left to pile up by local authorities, which has resulted in an increase in illegal dumping. Similarly, while there is a willingness to recycle, this action is minimal due to prohibitive costs and a lack of proper systems and facilities. Clean-up campaigns are frequently conducted in places of attraction such as beaches and rivers; this practice should, however, be expanded as an island-wide initiative. Heavy rainfall often causes floods because of the pile up of garbage in the communities, which then gets washed down to the beaches. A view echoed across focus groups was that "if you clean your community, there would be no garbage in places of attraction." Tobagonians try to conserve energy, and acknowledge that the country's oil and gas reserves are depleting and that renewable energy is a far better alternative for the environment. Nevertheless, at the moment, hydrocarbon energy is cheap and there are few government incentives in place for green alternatives.

The model of community tourism development was brought up by several participants as a viable path to sustainable tourism. This has already been successfully adopted by the Tobago fishing village of Castara. Community tourism can contribute to most of the SDGs, but primarily Goal 11 (Sustainable cities and communities) and Goal 12 (Responsible production and consumption). The Castara community aims to preserve a green environment with strong community participation. It also preserves local heritage, art and culture, and the passing down of traditions to younger generations. The Castara Tourism Development Association brings together all businesses through a strong sense of community to promote a clean village, recycling, and protection of the environment. There is also a ban on styrofoam and plastic bags in the community, while 
government legislation lags behind. The marketing of the community is focused around repeat customers, and there is constant demand throughout the year. Stakeholders expressed that Castara is a sustainable model that could be replicated throughout the island. Other communities are, nonetheless, slow to follow. Although government intervention was not required in Castara, government support could spread the model to other parts of the island. Each community could develop their 'unique selling point'. In addition, local educational campaigns by the THA and the Tobago Tourism Agency could encourage the spread of community tourism development. The general objective of such a campaign should be to encourage pride in Tobago, which can then be translated into local action. Tobagonians also need to be educated about the need for sustainability, as well as the importance of tourism for the island and the opportunities that could be created.

Ecological research, management, protection, and conservation were identified as positive actions taking place on a small scale with significant potential to expand. These actions relate to Goal 13 (Climate action), Goal 14 (Life below water), and Goal 15 (Life on land). The Environmental Research Institute of Charlotteville (ERIC) looks after coral reefs, sharks, and stingrays, and is currently engaged in a coral gardening reef restoration program. The Turtle Village Trust and Save our Sea Turtles are two NGOs engaged in sea turtle protection and conservation, which also seek to educate the public on the importance of sea turtle protection and conservation, and offer guided tours of nesting beaches. The Improving Forest and Protected Area Management in Trinidad and Tobago (IFPA) includes two areas in Tobago: the Main Ridge Forest Reserve and the North-East Tobago Marine Protected Area. The 'Adopt a River' Program is an initiative to involve the community and corporate entities in the improvement of watersheds. Focus group participants deemed this kind of research and conservation action essential, and expressed that increased research and data collection were vital for more informed decisions by policy makers and other stakeholders to make tourism sustainable. There is also illegal logging, dumping, and hunting taking place, a result of weak legislation and education campaigns, accompanied by poor enforcement due to a workforce shortage for patrols.

\subsection{Sustainable tourism barriers}

The focus groups provided information on the main obstacles to implementing sustainable tourism practices. These obstacles also threaten realising the SDGs. The THA was perceived as lacking action in effective management and administration of sustainable tourism practices and policy implementation. This is directly associated with Goal 16 (Peace, justice, and strong institutions). This may possibly arise from the dependency on the mainland for revenue and a ready source market of domestic tourists. A common view voiced was that the THA is not "pushing hard enough" to develop sustainable tourism in Tobago. One participant gave the example of a number of big hotel projects which were lost because of difficulty in obtaining land licenses. The THA receives its annual budgetary allocation from the government of Trinidad and Tobago, where the majority of the revenue comes from the energy sector. There is also 
a dependence on arrivals from Trinidad throughout the year. Only in times of low energy prices is there "talk of diversification," with sustainable tourism in Tobago being identified as a key sector, but there is no real follow up action by policy makers.

A common view also expressed was that political affiliation of the THA to the government of Trinidad and Tobago had somewhat hindered tourism development. While Tobago remains dependent on the mainland for transport links, stakeholders felt that the THA could have done more to lobby the government to improve reliability of these links. This combination of mainland dependency and political ties within organizations has hampered tourism in Tobago, as demonstrated in the THA's handling of the air and sea bridge problems in 2016. The THA appeared absent in finding a solution to the unreliability of the domestic sea and air bridge to get tourists and supplies to the island. The issue impacted everyone on the island, and businesses repeatedly raised their voices to get some kind of relief. The inter-island transport problem is related to Goal 9 (Industry, innovation, and infrastructure). This resulted in Tobago losing the majority of its domestic tourist market because of a "lack of confidence in the air and sea bridge," upon which the island is very heavily dependent, since international arrivals have decreased considerably. This has also led to the "skyrocketing" of prices of products on the island.

Focus group participants stated that persons with local knowledge of the problems facing the tourism sector who can offer practical solutions are sometimes left outside of the decision making process. The THA is the single largest employer on the island, employing a large segment of the population through make-work and unemployment relief programs. This may negatively affect tourism, as it makes it difficult for the tourism and private sectors to find reliable workers; people prefer to work for the THA because it is a "steady and easy job." It also limits entrepreneurship in the tourism sector, since earning an income is more or less guaranteed by the local government. Stakeholders concurred that there should be more emphasis by the THA to transition persons out of unproductive into productive work.

Another obstacle is that financing from banks and other final institutions is difficult and costly to obtain. It was felt that more government support systems and incentives to develop small businesses are needed. When young professionals return home to Tobago after completing their university education, there is a "struggle" to find a job. If these persons are not working for the THA, they are working in a low skill job not suitable to their qualifications. These persons have an interest in self-employment but require support. Most of them have no choice but to leave the island because there are no opportunities available; this can negatively affect Goal 8 (Decent work and economic growth) and Goal 10 (Reduced inequalities).

If funds are available to counteract the prohibitive costs of sustainable practices, the rate of implementation would be much higher. There are limited financing opportunities from banks and other financial institutions. Political status may, at times, disadvantage Tobago from receiving international funding; international funding goes to the country first, and a portion is then allocated to the sub-national jurisdiction. Also, NGOs based on or working in Tobago find it more difficult to access funding, especially 
from international sources, because of the relatively small size of projects implemented on the island. Further, such NGOs do not have the resources to submit comprehensive proposals to win international funding, nor can they afford to have audited accounts which oftentimes are a prerequisite to applying for these funds. Additionally, although businesses pay Green Fund Levy taxes quarterly into a fund for distribution to NGOs and communities for projects related to reforestation and conservation of the environment, focus group participants relayed that it is almost impossible to access these funds.

\section{Discussion and conclusion}

This study adds to the limited research on sustainable tourism, the SDGs, and tourism stakeholders. The study considered the extent to which sustainable tourism contributes to achieving the SDGs and how tourism stakeholders understand and implement sustainable tourism in a SNIJ. It provides evidence of the sustainable capacities and potential of Tobago, which can translate into the achievement of the SDGs, and engaged island stakeholders in its assessment of sustainable tourism and the SDGs. The findings of the study provide an opportunity for Tobago, in the post-COVID19 period, to re-open and re-build its tourism industry in a sustainable manner in conjunction with achieving the SDGs.

There were limitations to the study. Firstly, the findings of the paper were based on a single case study. The study did, however, reveal a number of issues that may have important implications for other SNIJs, and for island economies more generally. Second, the study aimed to have 10 participants present in each focus group and, while 10 to 12 participants were confirmed to attend each focus group, there were no-shows on the day. Nonetheless, the discussions were rich, with each focus group lasting around 2 to 2.5 hours. Lastly, a purposive random sampling was used. While this allowed the study to identify tourism stakeholders with intimate knowledge of the island, the sample was not representative.

The results suggest that tourism stakeholders, despite their lack of understanding, embraced the SDGs, and see value in the SDGs contributing to sustainable tourism. Movono and Hughes (2020), in their study of tourism in Fiji, and Özgit and Zhandildina (2021), in their study in North Cyprus, similarly found a lack of knowledge of the SDGs but a high level of acceptance by stakeholders. Additionally, stakeholders were unable to provide a clear and comprehensive definition of sustainable tourism. There were concerns that the concept is not fixed, nor is it easy to measure, and may even be impossible to achieve. Movono and Hughes (2020) exposed a similar paradox between tourism growth and sustainable development and the SDGs among tourism stakeholders in Fiji. Participants nonetheless recognised the traditional components of sustainable tourism, including meeting the needs of current and future generations, as well as the economic importance of the industry and the need to minimise negative environmental and social impacts. These components were overlapping and contained in the traditional definitions of sustainable development 
and sustainable tourism found in the literature, including studies by Gunn (1994), Hardy and Beeton (2001), Ioannides (1995), and Robson and Robson (1996). Specific island features were also incorporated into the definition of sustainable tourism, including isolation, existential threats, the importance of carrying capacity and community, as well as the island-to-metropole mainland relationship, and sovereignty and dependency (Apostolopoulos \& Gayle, 2002; Briguglio et al., 2006; Kelman, 2021; Peterson, 2020).

Stakeholders more easily listed sustainable tourism practices and potential on the island which are interrelated with the SDGs. The actions identified relate closely to the areas that the UNWTO (2018) identified as tourism stakeholder actions that can better contribute to the SDGs, such as resource efficiency, environmental protection and climate change initiatives, and adoption of cultural values. This demonstrates a characteristic of resilience of persons living in Tobago. At the top of the list - and identified in all three focus groups - was a reliable transport link from the mainland to the island, as well as international links to the island, without which there would be no tourism sector (Goal 9: Industry, innovation and infrastructure). This finding is not surprising given that the literature does highlight that SNIJs such as Tobago face severe transport challenges which can negatively affect tourism (Armstrong \& Read, 1998, 2000; Baldacchino, 2004).

Other factors specified by stakeholders included the commercial viability of the tourism product and destination marketing directed to Tobago only (Goal 8: Decent work and economic growth). According to Kelman (2021), island sustainability branding has become important for tourism around the world. Household or individual level action, specifically garbage disposal and recycling, clean-up campaigns, and energy conservation, were also seen as important (Goal 6: Clean water and sanitation; Goal 7: Affordable and clean energy; and Goal 11: Sustainable cities and communities). The literature does highlight that tourism-related waste is a concern for island sustainability - as tourists can generate twice as much waste as locals - and also highlights the implementation challenges of 'reduce, reuse, and recycle' on islands (Kelman, 2021). Additionally, Kelman (2021) purports that energy-related efforts should be at the forefront of island sustainability, as islands experience energy overuse due to tourism.

The model of community tourism development was brought up by several participants as a viable path to sustainable tourism (Goal 11: Sustainable cities and communities). Tourism is described in the literature as a powerful tool for community development and for reducing inequalities if it engages the community in its development (UNWTO, 2015). In Fiji, Movono and Hughes (2020) showed the importance of partnerships between tourism businesses and the local community to support development outcomes and contribute to the attainment of the SDGs. Ecological research, management, protection, and conservation were also identified as positive actions taking place in Tobago. These actions occur on a small scale with significant potential to expand (Goal 11: Sustainable cities and communities; Goal 13: Climate action; Goal 14: Life below water; and Goal 15: Life on land). In line with this, 
Rasoolimanesh et al. (2020), in their review of the literature on sustainability indicators and the SDGs, found that environmental protection and ecological research was important.

The barriers to sustainable tourism centred mainly on the role of the THA and its political affiliation to the government, and Tobago's dependency on the mainland. The THA came under attack for its perceived lack of action and policy implementation (Goal 16: Peace, justice, and strong institutions). SNIJs are regarded as politically powerless in the literature, and islands tend to be in a position of political subordination to the mainland (Lim \& Cooper, 2008; Royle, 2001). Unsuitable persons may be placed in decision-making positions, while persons with local knowledge and solutions were left out (Goal 8: Decent work and economic growth; and Goal 10: Reduced inequalities). In addition, make-work programs result in labour shortages for the private sector (Goal 8: Decent work and economic growth; and Goal 10: Reduced inequalities). According to Rasoolimanesh et al. (2020), governance is inseparable from SDG implementation, as the state has to define specified targets and timelines and develop appropriate implementation processes. Moreover, sustainable tourism requires an effective process of governance adjusted to specific purposes and contexts (Rasoolimanesh et al., 2020).

The prohibitive costs of implementing sustainable initiatives in the tourism sector were also a major obstacle. Further, Tobago may be disadvantaged in accessing finance because of its political status as a SNIJ. Hess and Kelman (2017) explored the potential of the tourism industry in providing financing for sustainable development; they identified fiscal and political mechanisms such as adaptation taxes and levies, adaptation funds, building regulations, and risk transference as valuable sources of finance. Some of these financing mechanisms may apply in the Tobago context.

In conclusion, the study revealed that tourism stakeholders in Tobago embrace the SDGs and have an interest in developing sustainable tourism on the island. Stakeholders identified reliable transport links, destination marketing, community tourism, household action and environmental protection, and ecological research as areas that can be expanded to improve sustainable outcomes. Financing, dependency on the mainland, and the role of the THA and its political affiliation to the government were recognized as key barriers. Action is needed to facilitate broad-based stakeholder awareness and collaboration in support of efforts to enhance Tobago's sustainability, and, in this endeavour, the THA and government, as the principal policymakers, need to act as a catalyst for change.

\section{References}

Apostolopoulos, Y., \& Gayle, D. J. (Eds.). (2002). Island tourism and sustainable development: Caribbean, Pacific and Mediterranean experiences. Praeger.

Armstrong, H. W., \& Read, R. (2000). Comparing the economic performance of dependent territories and sovereign microstates. Economic Development and Cultural Change, 48(2), 285-306. https://doi.org/10.1086/452459 
Armstrong, H. W., \& Read, R. (1998, July 1-5). The international political economy of micro-states: An overview [Conference presentation]. International Small Islands Studies Association (ISISA) 'Islands of the World V' Conference, University of Mauritius, Mauritius.

Baldacchino, G. (2006). Islands, Island Studies, Island Studies Journal. Island Studies Journal, 1(1), 3-18.

Baldacchino, G. (2004). Autonomous but not sovereign? A review of island subnationalism. Canadian Review of Studies in Nationalism, 31(1-2), 77-89.

Barrows, C. W. (2000). An exploratory study of food and beverage training in private clubs. International Journal of Contemporary Hospitality Management, 12(3), 190-197. https://doi.org/10.1108/09596110010320751

Berry, S., \& Ladkin, A. (1997). Sustainable tourism: A regional perspective. Tourism Management, 18(7), 433-440. https://doi.org/10.1016/s0261-5177(97)00053$\underline{8}$

Boddy, C. (2005). A rose by any other name may smell as sweet but "group discussion" is not another name for a "focus group" nor should it be. Qualitative Market Research: An International Journal, 8(3), 248-255. https://doi.org/10.1108/13522750510603325

Bramwell, B., \& Lane, B. (1993). Interpretation and sustainable tourism: The potential and pitfalls. Journal of Sustainable Tourism, 1(2), 71-80. https://doi.org/10.1080/09669589309450706

Briguglio, L., Cordina, G., \& Kisanga, E. J. (2006). Building the economic resilience of small states. University of Malta and Commonwealth Secretariat.

Byrd, E. T. (2007). Stakeholders in sustainable tourism development and their role: Applying stakeholder theory to sustainable development. Tourism Review, 62(2), 613. https://doi.org/10.1108/16605370780000309

Central Statistical Office of Trinidad and Tobago. (2019). Number of business establishments by employment size and region (Corporations). Business Surveys Establishment Register 2018. https://cso.gov.tt/subjects/business-andindustry-2/

Choi, H. C., \& Sirakaya, E. (2006). Sustainability indicators for managing community tourism. Tourism Management, 27(6), 1274-1289. https://doi.org/10.1016/j.tourman.2005.05.018

Dodds, R., \& Butler, R. (Eds.). (2019). Overtourism: Issues, realities and solutions (Vol. 1). De Gruyter.

Government of the Republic of Trinidad and Tobago. (2016). Vision 2030: The National Development Strategy of Trinidad and Tobago 2016-2030. Ministry of Planning and

Development. https://www.planning.gov.tt/sites/default/files/Vision\%202030-\%20The\%20 National\%20Development\%20Strategy\%20of\%20Trinidad\%20and\%20Tobago \%202016-2030.pdf 
Grydehøj, A., \& Kelman, I. (2017). The eco-island trap: Climate change mitigation and conspicuous sustainability. Area, 49, 106-113.

https://doi.org/10.1111/area.12300

Gunn, C. (1994). Tourism planning. Taylor \& Francis.

Hall, C. M. (2019). Constructing sustainable tourism development: The 2030 Agenda and the managerial ecology of sustainable tourism. Journal of Sustainable Tourism, 27(7), 1044-1060. https://doi.org/10.1080/09669582.2018.1560456

Hardy, A. L., \& Beeton, R. J. S. (2001). Sustainable tourism or maintainable tourism: Managing resources for more than average outcomes. Journal of Sustainable Tourism, 9(3), 168-192. https://doi.org/10.1080/09669580108667397

Hess, J., \& Kelman, I. (2017). Tourism industry financing of climate change adaptation: Exploring the potential in Small Island Developing States. Climate, Disaster and Development Journal, 2(2), 33-45. https://doi.org/10.18783/cddj.v002.i02.a04

Hines, T. (2000). An evaluation of two qualitative methods (focus group interviews and cognitive maps) for conducting research into entrepreneurial decision making. Qualitative Market Research: An International Journal, 3(1), 7-16. https://doi.org/10.1108/13522750010310406

Inskeep, E. (1991). Tourism planning: An integrated and sustainable development approach. Van Nostrand Reinhold.

InvesTT. (2019). Tourism infographics. http://www.investt.co.tt/publications/

Ioannides, D. (1995). A flawed implementation of sustainable tourism: The experience of Akamas, Cyprus. Tourism Management, 16(8), 583-592. https://doi.org/10.1016/0261-5177(95)00081-x

Kelman, I. (2021). Critiques of island sustainability in tourism. Tourism Geographies, 23(3), 397-414. http://doi.org/10.1080/14616688.2019.1619825

Ko, T. G. (2005). Development of a tourism sustainability assessment procedure: A conceptual approach. Tourism Management, 26(3), 431-445. https://doi.org/10.1016/j.tourman.2003.12.003

Krueger, R. A. (1994). Focus groups: A practical guide for applied research. Sage.

Lelaulu, L. (1994). Safe tourism: It is possible. Our Planet (UNEP), 6(1), 17-18.

Lim, C., \& Cooper, C. (2008). Beyond sustainability: Optimising island tourism development. International Journal of Tourism Research, 11(1), 89-103. https://doi.org/10.1002/jtr.688

McCool, S. F. (1995). Linking tourism, the environment and concepts of sustainability: Setting the stage. In S. F. McCool \& A. E. Watson (Eds.), Linking tourism the environment and sustainability - Topical volume of compiled papers from a special session of the annual meeting of the National Recreation and Park Association (pp. 3-7). United States Department of Agriculture - Forest Service.

McElroy, J. L. (2003). Tourism development in small islands across the world. Geografiska Annaler B, 85(4), 231-242. https://doi.org/10.1111/j.0435$\underline{3684.2003 .00145 . x}$

McElroy, J. L., \& Albuquerque, K. D.(2002). Problems for managing sustainable tourism in small islands. In Y. Apostolopoulos \& D. J. Gayle (Eds.), Island tourism and 
sustainable development: Caribbean, Pacific, and Mediterranean experiences (pp. 15-34). Praeger.

McElroy, J. L., \& Mahoney, M. (1999). The propensity for political dependence in island microstates. INSULA: International Journal of Island Affairs, 9(1), 32-35.

Milano, C., Cheer, J. M., \& Novelli, M. (2018). Overtourism: A growing global problem. The Conversation. https://theconversation.com/overtourism-a-growing-globalproblem-100029

Mooney, H., \& Zegarra, M. A. (2020). Extreme outlier: The pandemic's unprecedented shock to tourism in Latin America and the Caribbean [IDB Policy Brief 339]. InterAmerican Development Bank. https://doi.org/10.18235/0002470

Movono, A., \& Hughes, E. (2020). Tourism partnerships: Localizing the SDG Agenda in Fiji. Journal of Sustainable Tourism, Advance online publication. http://doi.org/10.1080/09669582.2020.1811291

Nielsen, J. (1997). The use and misuse of focus groups. IEEE Software, 14(1), 94-95.

Özgit, H., \& Zhandildina, D. (2021). Investigating stakeholder awareness of the sustainable development goals and tourism stakeholder collaboration: The case of North Cyprus. World Hospitality and Tourism Themes, 13(4), 498-509. http://dx.doi.org/10.1108/WHATT-02-2021-0027

Peterson, R. R. (2020). Over the Caribbean top: Community well-being and overtourism in small island tourism economies. International Journal of Community Well-being, Advance online publication. https://doi.org/10.1007/s42413-02000094-3

Pigram, J. J. (1990). Sustainable tourism: Policy considerations. Journal of Tourism Studies, 1(2), 2-9.

Prince, M., \& Davies, M. (2001). Moderator teams: An extension to focus group methodology. Qualitative Market Research: An International Journal, 4(4), 207216. https://doi.org/10.1108/eum0000000005902

Randall, J. E. (Ed.). (2020). The 21st Century Maritime Silk Road Islands Economic Cooperation Forum: Annual report on global islands 2019. Island Studies Press.

Rasoolimanesh, S. M., Ramakrishna, S., Hall, C. M., Esfandiar, K., \& Seyfi, S. (2020). A systematic scoping review of sustainable tourism indicators in relation to the sustainable development goals. Journal of Sustainable Tourism, Advance online publication. http://doi.org/10.1080/09669582.2020.1775621

Robson, J., \& Robson, I. (1996). From shareholders to stakeholders: Critical issues for tourism marketers. Tourism Management, 17(7), 533-540. https://doi.org/10.1016/s0261-5177(96)00070-2

Royle, S. A. (2001). A geography of islands: Small island insularity. Routledge.

Schmidt, M. (2001). Using an ANN-approach for analysing focus groups. Qualitative Market Research: An International Journal, 4(2), 100-111.

Southgate, C., \& Sharpley, R. (2002). Tourism, development and the environment. In R. Sharpley \& D. Telfer. (Eds.), Tourism and development: Concepts and issues (pp. 231-262). Channel View. https://doi.org/10.21832/9781845414740-011

Stewart, D. W., \& Shamdasani, P. N. (1990). Focus groups: Theory and practice. Sage. 
Tobago House of Assembly. (2019). Tourism Statistics. https://cso.gov.tt/subjects/travel-and-tourism/tourism-statistics/

Threlfall, K. D. (1999). Using focus groups as a consumer research tool. Journal of Marketing Practice: Applied Marketing Science, 5(4), 102-105. https://doi.org/10.1108/eum0000000004560

Tobago Tourism. (n.d.). About Tobago Tourism. https://www.visittobago.gov.tt/corporate/about-tobago-tourism

Twining-Ward, L., \& Butler, R. (2002). Implementing STD on a small island: Development and use of sustainable tourism development indicators in Samoa. Journal of Sustainable Tourism, 10(5), 363-388. https://doi.org/10.1080/09669580208667174

T\&T NGO News. (n.d.). Tobago NGO Directory. https://ttngo-news.com/tobago-ngodirectory/

World Bank Group. (2021). World Development Indicators. Data Bank. https://databank.worldbank.org/source/world-development-indicators

World Tourism Organization. (2020). World Tourism Barometer May 2020 - Special focus on the impact of COVID-19. UNWTO. https://doi.org/10.18111/9789284421817

World Tourism Organization. (2018). Tourism and the Sustainable Development Goals - Journey to 2030. UNWTO. https://doi.org/10.18111/9789284419401

World Tourism Organization. (2015). Tourism and the Sustainable Development Goals. UNWTO. https://doi.org/10.18111/9789284417254

World Tourism Organization. (1998). Guide for local authorities on developing sustainable tourism. UNWTO. http://doi.org/10.18111/9789284402809

World Travel and Tourism Council. (2019). Travel \& tourism: Global economic impact \& trends 2019. WTTC.

Yuksel, F., Bramwell, B., \& Yuksel, A. (1999). Stakeholder interviews and tourism planning at Pamukkale, Turkey. Tourism Management, 20(3), 351-360. https://doi.org/10.1016/s0261-5177(98)00117-4 